\title{
REIT Performance and Option of Financing Real Estate Project in Developing Countries - (A Case of M-REIT and N- REIT)
}

\author{
Olusegun Olaopin Olanrele ${ }^{1}$, Rosli Said ${ }^{2}$, Md Nasir Daud ${ }^{3}$ \\ 1,2,3 Department of Estate Management, Faculty of Built Environment, University of Malaya, 50603, \\ Kuala Lumpur, Malaysia
}

\begin{abstract}
Performance of REITs have been largely measured using benchmark from the stock market indices (S\&P500, Sharpe ratio, KLCI, etc) or correlation studies. The real world of REIT shows that both economic and environmental factors exert influence on REIT performance on a simultaneous nature. Adopting quantitative method, where secondary data were statistically analysed. We proposed the use of multivariate regression where REIT performance $(\mathrm{Y})$ is the independent variable to be predicted by predictor variables of internal and external factors $\left(\mathrm{X}_{1}-\mathrm{X}_{\mathrm{n}}\right)$. We equally proposed a possibility of REIT financing real estate project, against the existing regulations which prohibit such, using average return method of portfolio analysis on assumed numerical data. The study finds that economic factors jointly have a significant effect on REIT performance at $\mathrm{P}=$ 0.044 while none of the factors has significant contribution individually. A benchmark REIT return of $5.3 \%$ is predicted. The study recommends a linear regression model analysis for REITs benchmark based on past performance for return measurement. REIT can only finance real estate project in the countries where there is acute shortage of fund and property stock. We suggest a modification of REIT laws to accommodate real estate financing by REITs.
\end{abstract}

\section{Introduction}

Real Estate Investment Trusts (REITs) are companies similar to mutual funds that hold portfolios of real estate and real estate related financial instruments for the benefit of their shareholder. REIT as a recent alternative investment medium for real estate has gained more recognition and acceptance in the developed (Western) world for a period now. However in the emerging economics of Africa and Asia, the adoption of REITs is more recent. REITs took a centre stage in Nigeria with the N50bn Union Homes Hybrid REIT launched in September 2008 (after N2bn Skye Shelter Fund launched in 2007) following the issuance of guidelines for registration and requirement for operation by the Securities and Exchange Commission (SEC) in 2007 [1]. Since the existence of REIT in Nigeria in 2007, little achievements have been recorded. REIT in Malaysia started in form of listed property trust (LPT) in 1989 as a pioneer of REIT industry in Asia. M-REITs in modern form listed in Malaysia stock Exchange with 17 REITS (both Islamic and Commercial REITs as at November, 2013) came into existence in 2005. In Africa in general, REITs came into existence in 1994 in Ghana and 2002 in South Africa in form of Property Unit Trust (PUT) and Property Loans Stock Company (PLS Company). Effort is being made to transform to modern form of REIT in South Africa [2]. The 
operations of Real Estate Investment Trust (REIT) is tailored towards investing on real estate products, especially investment (income generating) properties like offices, retail properties, industrial, high rise income yielding residential properties (condominium) etc. In so doing, REIT could be making fund available (indirectly) for real estate development and thereby stimulating the real estate sector. This paper analyses the performance of REITs through multivariate regression and appraise the possibility of financing real estate development with REITs fund in the eye of the regulatory framework and REIT laws using hypothetical portfolio average return syntax.

\section{Performance Measurements and Benchmarking of REIT Returns}

Performance measurement/analysis is the process of ascertaining the degree at which organizational goals are met and how. Measurement of REIT return can be viewed from the income and return generation perspectives and can be literarily explained in terms of its operational success which is revealed in its profitability to the investors. REIT markets have proved extremely successful in U.S. and Australia, with steady growth in the REIT markets in Asia and in Europe [3]. In general, the performance of REITs is mainly determined by the different types of investments the companies make, which is basically divided into Equity REIT, Mortgage REIT and hybrid REIT. Returns from REITs are primarily derived from rents from their property assets and capital appreciation and it is expresses in form of dividend as it is for any other investment instrument in the stock/capital market and could be measured in percentages (\%) or money units (e.g cents or Ringgit). Studies have identified the attributes that affect REIT return to include Net Asset Value (NAV), Capitalisation (otherwise known as 'Size'), Funds From Operation (FFO), Leverage (or Gearing) and Market-toBook Value (Asset Value). These attributes were considered each in isolation of the other in the past studies but the reality is that each and every one of the identified factor attributes is exerting influence on REITs performance simultaneously.

In the studies of REIT performance and measurement, authors have focused on each determinant factor that contributed to the yield while holding other factor(s) constant or of no simultaneous effect. Yong et. al. [4] using a multi-factor approach to analyse Australian REIT (A-REIT) returns, identified size (in terms of capitalisation); degree of leverage (Gearing) and market-to-book (Value) ratio among others as the determinant of REIT returns. The significance of the value stock has been increasing for REITs since 1990 and plays an important role in diversification of REITs across continents rather than across countries [5]. For the size (capitalisation) factor, studies had suggested that there is an inverse relationship between returns and size implying that smaller yields tend to yield more return than the larger REIT. Yong et. al. [4] however added that the negative impact of size is diminishing over time. Larger REITs are found to be more geographically diversified but less diversified across property types and this could result in negative relationship of size to return [5,6]. Yong et. al. [4] found and concluded that size factor had a negative impact on return and was only found to be a determinant of returns before 1996 (prior to Asia financial crisis of 1997). There is a positive relationship between REIT size, Revenue and Profit [7,8]. Positive economies of scale effects can be achieved by larger asset size but its efficiency may also diminish when the span of control is exceeded [9]. REIT stock out-performance in Europe to size, specialisation and geographic focus [10]. This finding however, contradicted the negative relationship between size and returns of [4]. A detailed study has to be carried out before generalising on the factors affecting REITs performance [7].

The degree of influence of leverage on returns was found to be significant. Leverage magnifies both positive and negative investment returns, resulting in pronounced gain and losses [11]. The relationship between the leverage/gearing was found to be positive but not significant and that more leveraged REITs are more sensitive to macroeconomic factors. A short term interest rate has inverse relationship with return while a long term interest rate posits a positive relationship. A short term interest rate has negative relationship with return while long term interest has positive relationship with return $[11,12]$. However a contrasting result that there is a significant negative relationship between long term interest rates and returns, with a positive insignificant relationship with short term interest rates [13]. Hwa et. al. [14] studied stability of dividend and FFO (fund from operation) in 
Malaysia, They concluded that the dividend (return) declared by REITs/Listed Property Trusts are not stable because it is affected by FFO (the net income from the underlying property assets). Excess dividends are a function of a firm's capacity to generate FFO $[15,16]$. Other researchers on the contrary concluded that the REIT industry's claim of FFO superiority is premature as the examination of cash flow volatility and dividend pay-out concluded that there is a negative relationship between cash flow volatility and dividend level. FFOs are in turn affected by other economic factors [7]. Ong et. al. [17] studied the performance of Malaysian REITs from 2005 - 2010 using Net Asset Value (NAV) per unit. An investment that trade at a market price that is below the NAV is perceived to have positive growth potentials NAV while one with market price above NAV signals to investors, a negative growth opportunities for the REIT. NAV is a function of the net market value of the underlying real property assets of the REIT Company spread over the total outstanding units of the REIT Company. Hua [18] affirmed that NAV is used to measure per share of company's net asset market value, which is then compare with the share price of the company to determine performance. REITs trading at high or low premium or even at discount have been discovered to be a result of investors' sentiments in most cases. NAV therefore may not be a determinant of yield, but a unit of comparison to determine performance of REIT.

In every investment performance studies, there is always a benchmark for comparison and decision. REIT performance analysis has been premised on benchmarking wherein the return from REITs is compared against market indices. The problem is not of benchmarking but of the benchmark (e.g. KLCI, S\&P/ASX200 or Sharpe ratio index etc.). Nevell et. al. [19] discovered that Amanah Harta Tanah PNB is the only REIT, out of 4 other samples to outperform KLCI index and the Kuala Lumpur Properties Index (KLPI) for the period of 1991 till 2000 period. (The study in effect used the KLCI and KLPI as bench mark). These indices focused on the capital market elements and factors like return from the other forms of investment. The proposition here is that a benchmark for REIT performance should be set by the forecast of return from REIT based on the simultaneity effect of REIT characteristics. While there is need for a yardstick to be set in REITs performance analysis, this study believed that such yardstick/benchmark should be predicted by the past performances of REIT industry. Since it has been proved in past studies that REITs return depends on NAV, FFO, Size, Gearing and Asset Value, the relationship between these component factor determinants and REITs return should be established to make a more realistic forecast of a benchmark. This could be achieved through a regression analysis to establish a linear relationship for the forecast of REITs return benchmark. A regression analysis will have consideration for the peculiar nature of the underlying asset of REIT- real property and the operating environment.

\section{REIT and Real Estate Financing}

Development of land (real estate) requires huge capital that developer and investors (especially private ones) are not always able to provide alone but requiring credit financing from various sources. Financing real estate development in the developing countries (in recent times) has become more problematic due to the complex interaction of several factors from high interest rates on loans, stringent repayment requirements, cumbersome loan requirements from lenders and availability of funds (as obtainable in Nigeria). In the face of acute shortage of real estate stock and lack of funds for development of real estate in some developing economies like Nigeria, the operations and performance of REITs is negatively affected. The emergence of the contemporary indirect sources of finance like securitization, unitization and real estate investment trusts (REITs) indicates that the huge capital requirement for real estate development cannot be met by established conventional sources and REIT has been identified as a suitable products that can serve as an outlets for the deployment of funds to real estate sector [1].The operational guidelines for REITs indicated that $75 \%$ of fund be used to acquire real estate assets leaving $25 \%$ for other investment option including real estate related investment vehicles like Mortgage Backed Securities (MBS). These are indirect way of making fund available to the real estate producers. REIT regulations practically discourage direct real estate financing. If the REIT companies are allowed to finance a project in property stock deficient 
economies, such fund deployed into real estate financing could be available at a lower rate which could stimulate development in real estate sector by contributing into the creation of real estate assets. The prominent role of REITs in financing commercial real estate in US was noticed in mid 1990s. REITs have turned to development as a core piece of their investment strategy [20]. They however cautioned that to remain qualified for tax exemption at the corporate level, REITs should avoid 'bad income' which when exceeds $5 \%$ of the aggregate income will be taxable at the prevailing rate. Payment of tax on 'Bad Income' may worth it if (only) the portfolio return will be higher than return from real estate investment. The question here is "what is the return if the $30 \%$ or less of the REITs fund is diversified to real estate financing with acceptance of paying income tax on the profit/income from real estate financing activities? Could there be a better portfolio return?"

\section{Methodology}

The study adopted quantitative method. Statistical analyses were performed on the data set collected in respect of the market/economic factor determinants from annual reports of AMFIRST REIT (a REIT company in Malaysia) for the period 2007 to 2013. A regression analysis was then performed on the data set using SPSS software, holding dividend as the dependent variable and other variables as determinant factors. The relationship looks thus:

Then,

$$
\mathrm{D}=\mathrm{f}\left(\mathrm{X}_{1} \ldots \mathrm{X}_{\mathrm{n}}\right)
$$

$$
\mathrm{D}=\mathrm{a}_{\mathrm{o}}+\mathrm{a}_{1} \mathrm{X}_{1}+\mathrm{a}_{2} \mathrm{X}_{2}+\mathrm{a}_{3} \mathrm{X}_{3}+\ldots+\mathrm{a}_{\mathrm{n}} \mathrm{X}_{\mathrm{n}}
$$

Where, $\mathrm{D}=$ dividend, $\mathrm{a}_{\mathrm{o}}$ is the intercept, $\mathrm{a}_{1}-\mathrm{a}_{\mathrm{n}}$ are slopes and $\mathrm{X}_{1}-\mathrm{X}_{\mathrm{n}}$ are predictor variables.

The study also made a numerical expression of possibility of deployment of REIT fund to real estate financing.

We demonstrated the deployment of $25 \%$ REIT fund to direct real estate financing following the portfolio average

return formula:

$$
r_{p}=f_{A} r_{A}+f_{B} r_{B}
$$

Where, A and B are investment options (Real estate asset and Financing respectively), $\mathrm{f}=$ fund allocated to each investment option and $\mathrm{r}=$ returns and $\mathrm{p}$ stand for the portfolio.

\begin{tabular}{|c|c|c|c|c|c|c|}
\hline Year & $\begin{array}{l}\text { NAV/ } \\
\text { (RM) }\end{array}$ & Size (RM'm) & $\begin{array}{l}\text { FFO } \\
\text { (RM'm) }\end{array}$ & $\begin{array}{l}\text { Leverage } \\
(\mathrm{RM} \text { 'm) }\end{array}$ & $\begin{array}{ll}\begin{array}{l}\text { Asset } \\
\text { (RM'bn) }\end{array} & \\
\end{array}$ & $\begin{array}{l}\text { Dividend } \\
\text { (Cent) }\end{array}$ \\
\hline 2007 & 1.00 & 424711.00 & 8.35 & 65.50 & 501.70 & 1.95 \\
\hline 2008 & 1.03 & 383955.90 & 31.31 & 395.60 & 852.10 & 7.30 \\
\hline 2009 & 1.32 & 373230.87 & 37.54 & 402.00 & 980.00 & 8.75 \\
\hline 2010 & 1.35 & 364650.85 & 23.53 & 413.00 & 1008.00 & 9.75 \\
\hline 2011 & 1.36 & 471901.10 & 14.42 & 407.00 & 1024.00 & 9.75 \\
\hline 2012 & 1.39 & 497641.16 & 23.18 & 380.00 & 1179.80 & 9.31 \\
\hline 2013 & 1.18 & 816818.38 & 17.69 & 88.40 & 1277.20 & 6.81 \\
\hline
\end{tabular}

\section{Data Analysis and Result}

Table 1: Extracted data set from annual report of AMREIT for period 2007-2013

Source: AmFirst REIT

Table 1 above indicates that one factor in exclusion of other factors cannot determine the true actual return from REIT investment but all factors are impacting on returns simultaneously. This is because there is no perfect constant relationship between yield and any of the indicators independently. A multiple regression analysis was performed which gives standardised regression line. 


$$
\mathrm{D}=0.025 \mathrm{~N}+0.5285 \mathrm{~S}-0.109 \mathrm{I}+0.992 \mathrm{~L}+0.25 \mathrm{~V}
$$

Where $\mathrm{D}=$ Dividend (in cent), $\mathrm{N}=\mathrm{NAV}, \mathrm{S}=$ Size, $\mathrm{V}=$ Asset Value, $\mathrm{I}=\mathrm{FFO}$ and $\mathrm{L}=$ Leverage.

Table 2: Standardised Beta values, significance and correllations

\begin{tabular}{|c|c|c|c|c|c|c|c|}
\hline \multirow[t]{2}{*}{ Model } & \multirow{2}{*}{$\begin{array}{c}\begin{array}{c}\text { Standardized } \\
\text { Coefficients }\end{array} \\
\text { Beta }\end{array}$} & \multirow[t]{2}{*}{ Sig. } & \multicolumn{2}{|c|}{$\begin{array}{l}95.0 \% \text { Confidence } \\
\text { Interval for B }\end{array}$} & \multicolumn{3}{|c|}{ Correlations } \\
\hline & & & $\begin{array}{l}\text { Lower } \\
\text { Bound }\end{array}$ & $\begin{array}{l}\text { Upper } \\
\text { Bound }\end{array}$ & $\begin{array}{l}\text { Zero- } \\
\text { order }\end{array}$ & Partial & Part \\
\hline (Constant) & & .104 & -13.743 & 4.853 & & & \\
\hline NET ASSET VALUE & .025 & .734 & -11.673 & 12.519 & .857 & .406 & .011 \\
\hline CAPITALIZATION & .528 & .138 & .000 & .000 & .357 & 977 & .117 \\
\hline 1 ASSET VALUE & .025 & .851 & -.015 & 015 & .722 & .231 & .006 \\
\hline NET INCOME & -.109 & .218 & -.168 & .108 & .511 & -.942 & $072^{-}$ \\
\hline $\begin{array}{l}\text { OUTSTANDING } \\
\text { LOAN }\end{array}$ & .992 & .055 & .000 & .000 & .833 & .996 & .298 \\
\hline
\end{tabular}

Table 3: ANOVA of the Regression showing $\mathrm{F}$ and significant values at $\mathrm{P}<0.05$

\begin{tabular}{|rl|r|r|r|r|l|}
\hline Model & & Sum of Squares & Df & Mean Square & F & Sig. \\
\hline \multirow{2}{*}{1} & Regression & 46.119 & 5 & 9.224 & 302.73 & $.044^{\mathrm{b}}$ \\
& Residual & & & & 6 & \\
& Total & .030 & 1 & .030 & & \\
& & 46.149 & 6 & & & \\
\hline
\end{tabular}

a. Dependent Variable: DIVIDEND

b. Predictors: (Constant), OUTSTANDING LOAN, CAPITALIZATION, NET INCOME, NET ASSET VALUE, ASSET VALUE

At $\mathrm{P} \leq 0.05$, none of the independent variables have significant contribution to dividend. However, all the five considered independent variables jointly have significant contribution dividend with $\mathrm{P}$ value of 0.044 (Table 3). The residual of regression is 0.03 , the allowable error at $95 \%$ confidence level is 1.96 therefore the regression is validated at 0.03 error levels which is less than 1.96. We therefore concluded in affirmation of the simultaneity effect of all factor determinants to REIT return. Substituting the real values, the regression gave a predicted expected yield of 5.3\% per annum which could serve as benchmark for REIT industry in Malaysia.

The five year results of N-REIT as presented in figure 1 above shows consistent loss in value except for Skye Shelter REITs which gained 5.7\% and 3\% in 2008 and 2011 respectively. The aggregate loss by end of 2012 was 4.76\%. It was a loss scenario for the Union Homes Hybrid REIT from its listing day through the five year period under review with an aggregate loss of $83.87 \%$ in share price (and Size) by the end of 2012.

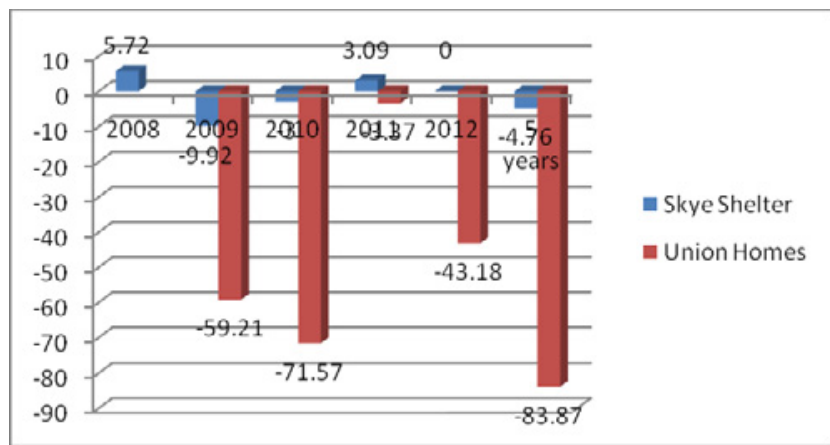

Figure 1: N-REIT Profile between 2008 and 2012 
For REITs, an option of financing could carry tax liability therefore adjustment is made to the equation (3) to incorporate tax (t). Thus:

$$
r_{p}=f_{A} r_{A}+f_{B} r_{B}-\left(f_{B} r_{B} x \text { tax rate }\right)
$$

We assumed and substituted into equation (5) above, the following data which are the current in both Malaysia and Nigeria. The data were collected from the websites of Bursa Malaya and Bank Negara in Malaysia and Central Bank of Nigeria respectively.

Fund is RM1, return from property $8 \%$, lending rate $4.6 \%$, and company tax $28 \%$ for Malaysia and Fund is NGN1, return from property $4 \%$, lending rate $22 \%$, and company tax $10 \%$ for Nigeria

Scenario 1 (Malaysia)

Portfolio Return $=(8 \% \times 75 \%)+(4.6 \% \times 25 \%)-(4.6 \% \times 25 \% \times 28 \%)=0.0683$

Scenario 2 (Nigeria)

Portfolio Return $=(4 \% \times 75 \%)+(22 \% \times 25 \%)-(22 \% \times 25 \% \times 10 \%)=0.0795$

The analysis gives a possible portfolio return of $6.83 \%$ and $7.95 \%$ for Malaysia and Nigeria respectively.

\section{Discussion and Conclusion}

Substituting the real values, the regression gave a predicted expected yield of $5.3 \%$ per annum which could serve as benchmark in Malaysia for REIT performance; the predicted benchmark is slightly higher than the FBMKLCI return rate of 5.23\% for September 2013. This implied that REITs in Malaysia could yield more return than the stock market index, KLCI. As at September, 2013, M-REIT yield is 6.26\% (Bursa Malaysia). Invariably none of the REIT companies is expected to yield less than the predicted benchmark. Similar analysis could not be performed for Nigeria REIT as the market has been unfavourable leading to loss in value for the years under review. The N-REIT suffered a sector loss of $85.8 \%$ over five years. The result show that M-REIT is performing better than N-REIT. Literature search reveal that the dismay performance of N-REIT is not only a function of the economic factors but other external factors relating to the operating environment. Societal acceptability is another factor in REITs return, [17] affirmed that institutional perception of an investment affects its performance rate. This means the way the society especially the investors perceive an investment will affect its return. It is therefore suspicious that the investors in Nigeria have not fully accepted REIT as a viable investment vehicle. We consider this literary analysis. Out of the Nigeria population of 140million people (2006 census), more than 10million are shareholders (registered with different shareholders association), excluding the low income earners who deploy their savings into paper investment. If each shareholder invested NGN100,000 in REIT, it will amount to NGN1trillion (RM20.17bn or US\$6.14bn,). The current total market size of NREITs is NGN3.7billion (RM74.56million or US\$22.65million). The share price trend of the listed REITs in Nigeria shows an indifference towards the REIT firms on the back of a low or narrow investor orientation to a near comatose stance for the sector in the last five years. This reflected more about market acceptability of the initiative over the last five years. The expectation of every investor is increase in profit and will always want to avoid tax payment. We find that financing real estate in Malaysia will give $6.83 \%$ portfolio return, a meager increase to what is realized already $(6.26 \%)$ without evaluating the associated risk for this increment. M-REIT will suffer loss in return because the lending rate is lower than the return from property investment. N-REIT on the other hand stands to benefit from real estate financing based on expected portfolio return of $7.95 \%$ from our analysis above. This is possible as Nigeria environment is characterized with low property return and high lending rate, perhaps this will help resuscitate the industry. The lack of property stock due to nonavailability of funds to finance real estate and exorbitant lending rate of over $22 \%$ could be 
responsible for poor performance of N-REIT. We conclude that REIT return benchmark should be set by the sector forecast based on past performances rather than stock market indices. We also affirmed that REIT could do better if allowed to finance real estate development in countries where there are acute shortage of property stock and absolute lack of fund to finance development of real property. Therefore a second look at the clause that prohibits financing by REITs is necessary.

\section{References}

1. Oreagba, F., Position paper on implementation of REIT in Nigeria (N-REIT): A seminar on Real Estate Investment Trust (REIT), 2010, Nigerian Stock Exchange.

2. Mathibe, B., Global REIT Survey: South Africa - PUT and PLS Company, 2012, EPRA.

3. Hoesli, M. and C. Lizieri, Real Estate in the Investment Portfolio. A report for the Investment Strategy Council 2007, Ministry of Finance: Norway. pp. 94-95.

4. Yong, J., D.E. Allen, and L.K. Lim, AREIT returns from 1990-2008: A multi-factor approach, in 18th World IMACS/MODSIM Congress2009: Cairns, Australia. pp. 1522 - 1529.

5. Hamelink, F. and M. Hoesli, What factors determine international real estate security returns. Real Estate Economics, 2004. 32(3): p. 437-462.

6. Chaudhry, M.K., S. Maheshwari, and J.R. Webb, REITs and idiosyncratic risk. Journal of Real Estate Research, 2004. 26(2): p. 207-222.

7. Alias, A. and C.Y. Soi Tho, Performance Analysis of REITS: Comparison between M-REITS and UK-REITS. Journal of Surveying, Construction and Property, 2011. 2: 38-61.

8. Ambrose, B.W., M.J. Highfield, and P.D. Linneman, Real Estate and Economies of Scale: The Case of REITs. Real Estate Economics, 2005. 33(2): 323 - 350.

9. Sing, T.F., Challenges Ahead for Singapore Real Estate Investment Trusts (S-REITs), 2005.

10. Brounen, D. and D.K. Sjoerd, Review articles: 50 YERAS OR REAL ESTATE INVESTMENT TRUSTS: AN INTERNATIONAL EXAMINATION OF THE RISE AND PERFORMANCE OF REITs. Journal of Real Estate Literature, 2012. 20(2): 197-223.

11. Allen, M.T., J. Madura, and T.M. Springer, REIT characteristisc and the sensitivity of REIT returns. Journal of Real Estate Finance and Economics, 2000. 21(2): 141-152.

12. Delcoure, N. and R. Dickens, REIT and REOC systematic risk sensitivity. Journal of Real Estate Research, 2004. 26(3): p. 237-254.

13. Ratcliffe, C. and B. Dimowski, The responsiveness of LPT returns and their attributes. Pacific Rim Property Research Journal, 2007. 13(3): 280-297.

14. Hwa, T.K. and M.Y. Abdul Rahman, Stability of Dividends and FFOs: The Case of REITs in Malaysia, in 13th Pacific Rim Real Estate Society Annual Conference 2007: Perth, Australia.

15. Feng, Z., S.M. Price, and C.F. Sirmans, An Overview of Equity Real Estate Investment Trusts (REITS): 1993 - 2009. Journal of Real Estate Literature, 2011. 19(2): 307 - 343.

16. Hardin III, W.G. and M.D. Hill, REIT Dividend Determinant: Excess Dividends and Capital Markets. Real Estate Economics, 2008. 36(2): 349 - 369.

17. Ong, T.S., B.H. The, and M.P. Chong, A Study on the Performance of Malaysian Real Estate Investment Trusts from 2005-2010 by using Net Asset Value Approach. International Journal of Economics and Research, 2011. 2(1): 1-15.

18. Hua, D., REIT Funds From Operations (FFO) Multiple Analysis, 2001, Golden Gate University.

19. Nevell, G., K.H. Ting, and P. Archeampong, Listed Property in Malaysia. Journal of Real Estate Literature, 2002. 10: 109-118.

20. Cunningham, R. and J.M. Ramey, Real Estate Investment Trusts (REITs) and Development: Avoiding Qualification Woes, in Financial Digest2006. 